University of Nebraska - Lincoln

DigitalCommons@University of Nebraska - Lincoln

USDA National Wildlife Research Center - Staff Publications
U.S. Department of Agriculture: Animal and Plant Health Inspection Service

2011

\title{
Land use and climate influences on waterbirds in the Prairie Potholes
}

\author{
Greg M. Forcey \\ North Dakota State University, research@gregforcey.com \\ Wayne E. Thogmartin \\ US Geological Survey Upper Midwest Environmental Sciences Center \\ George M. Linz \\ USDA/APHIS/WS National Wildlife Research Center, george.m.linz@aphis.usda.gov \\ William J. Bleier \\ North Dakota State University, William.Bleier@ndsu.nodak \\ Patrick C. McKann \\ US Geological Survey Upper Midwest Environmental Sciences Center
}

Follow this and additional works at: https://digitalcommons.unl.edu/icwdm_usdanwrc

Forcey, Greg M.; Thogmartin, Wayne E.; Linz, George M.; Bleier, William J.; and McKann, Patrick C., "Land use and climate influences on waterbirds in the Prairie Potholes" (2011). USDA National Wildlife Research Center - Staff Publications. 1319.

https://digitalcommons.unl.edu/icwdm_usdanwrc/1319

This Article is brought to you for free and open access by the U.S. Department of Agriculture: Animal and Plant Health Inspection Service at DigitalCommons@University of Nebraska - Lincoln. It has been accepted for inclusion in USDA National Wildlife Research Center - Staff Publications by an authorized administrator of DigitalCommons@University of Nebraska - Lincoln. 


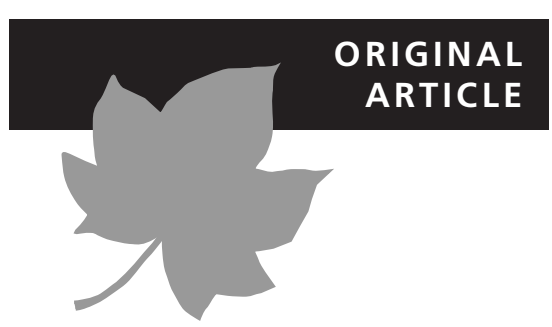

\title{
Land use and climate influences on waterbirds in the Prairie Potholes
}

\author{
Greg M. Forcey ${ }^{1 *}$, Wayne E. Thogmartin ${ }^{2}$, George M. Linz ${ }^{3}$, \\ William J. Bleier ${ }^{1}$ and Patrick C. McKann ${ }^{2}$
}

${ }^{1}$ Department of Biological Sciences, North Dakota State University, Fargo, ND 58105, USA, ${ }^{2}$ US Geological Survey Upper Midwest Environmental Sciences Center, 2630 Fanta Reed Road, La Crosse, WI 54603, USA, ${ }^{3}$ US Department of Agriculture, Wildlife Services, National Wildlife Research Center, 2110 Miriam Circle, Bismarck, ND 58501, USA

${ }^{*}$ Correspondence: Greg Forcey, Normandeau Associates Inc., $102 \mathrm{NE}$ 10th Ave, 1st Floor, Gainesville, FL 32601, USA.

E-mail: research@gregforcey.com

\begin{abstract}
Aim We examined the influences of regional climate and land-use variables on mallard (Anas platyrhynchos), blue-winged teal (Anas discors), ruddy duck (Oxyura jamaicensis) and pied-billed grebe (Podilymbus podiceps) abundances to inform conservation planning in the Prairie Pothole Region of the United States.

Location The US portion of Bird Conservation Region 11 (US-BCR11, the Prairie Potholes), which encompasses six states within the United States: Montana, North Dakota, South Dakota, Nebraska, Minnesota and Iowa.

Methods We used data from the North American Breeding Bird Survey (NABBS), the National Land Cover Data Set, and the National Climatic Data Center to model the effects of environmental variables on waterbird abundance. We evaluated land-use covariates at three logarithmically related spatial scales (1000, 10,000 and 100,000 ha), and constructed hierarchical spatial count models a priori using information from published habitat associations. Model fitting was performed using a hierarchical modelling approach within a Bayesian framework.
\end{abstract}

Results Models with the same variables expressed at different scales were often in the best model subset, indicating that the influence of spatial scale was small. Both land-use and climate variables contributed strongly to predicting waterbird abundance in US-BCR11. The strongest positive influences on waterbird abundance were the percentage of wetland area across all three spatial scales, herbaceous vegetation and precipitation variables. Other variables that we included in our models did not appear to influence waterbirds in this study.

Main conclusions Understanding the relationships of waterbird abundance to climate and land use may allow us to make predictions of future distribution and abundance as environmental factors change. Additionally, results from this study can suggest locations where conservation and management efforts should be focused.

\section{Keywords}

Abundance maps, Bayesian, Breeding Bird Survey, climate, ducks, hierarchical models, land use, Prairie Pothole Region, USA, waterbirds.

\section{INTRODUCTION}

Avian habitat studies are commonly used to assess how one or more species of birds respond to different environmental factors. Most previous studies examined bird-habitat relationships at small scales, focusing on microhabitats (e.g. Clark \& Weatherhead, 1986; Murkin et al., 1997; Vierling, 1999). Results from these site-intensive bird-habitat studies are sometimes extrapolated to a regional level because there is a paucity of larger-scale studies addressing these relationships (Thogmartin \& Knutson, 2007). Thus environmental effects on bird abundance that are present at larger scales can be overlooked or misattributed (Thogmartin, 2007).

While small-scale habitat studies are still common, the number of larger-scale habitat studies is growing because of the growing availability of readily accessible data. For example, 
large-scale data sets, such as the North American Breeding Bird Survey (NABBS) (Sauer et al., 2006), the National Land Cover Dataset (NLCD) (Vogelmann et al., 2001), and climate data from recording stations across the world (National Climatic Data Center, 2002) are freely available to those with internet access. Geographic information system software enables scientists to collect and analyse data across broad geographic areas that are necessary for large-scale habitat studies (Greenberg et al., 2002). High-speed computers have given researchers the capability of using powerful, but computationally intensive, Bayesian methods to create population-based models (Link \& Sauer, 2002; Calder et al., 2003; Thogmartin et al., 2004a). Bayesian approaches offer powerful tools to fit spatial habitat models over large scales because they can simultaneously account for Poisson overdispersion in count data, random effects associated with observer and year, and spatial autocorrelation (Thogmartin et al., 2004a).

Recent research examining landscape-level environmental influences on avian communities in North America found that birds are highly influenced by patterns in the landscape (Cushman \& McGarigal, 2002; Lichstein et al., 2002). Saab (1999) compared the influences of habitat variables at different scales and found that surrounding landscape features (the landscape matrix) were the most important predictors of bird presence. Neotropical migrant birds are especially sensitive to landscape features relative to temperate migrants and residents. Flather \& Sauer (1996) noted that Neotropical migrants were found in landscapes with a greater percentage of natural habitats and were negatively affected by increases in landscape diversity and edge. Abundances and distributions of wetland breeding birds have also been shown to be affected by largescale habitat variables. Fairbairn \& Dinsmore (2001) found landscape habitat variables to be important predictors of bird abundance for seven waterfowl and passerine species. Additionally, Naugle et al. (2000, 2001) identified total grassland and wetland area as important predictors of waterbird occurrence. Mallard (Anas platyrhynchos Linnaeus) abundance has also been shown to be affected by landscape influences, with abundance positively related to area of wetlands and rice, and negatively related to area of orchards and urban lands in the Central Valley of California (Newbold \& Eadie, 2004).

Birds can be affected differently by environmental factors at varying scales. Pribil \& Picman (1997) noted that the density of cattail (Typha spp., a common herbaceous wetland plant that often occurs at high densities) immediately around the nest, but not at broader scales, was an important factor in redwinged blackbird (Agelaius phoeniceus Linnaeus) nest site selection. Saab (1999) found strong bird-habitat relationships at landscape, microhabitat and macrohabitat scales, with landscape features the most important. The influence of scale in landscape analyses underscores the importance of examining landscape effects at multiple scales so that important relationships are not overlooked (Urban, 2005).

A relatively new approach to avian habitat studies is to examine environmental influences beyond the landscape scale to a regional (in the United States, multi-state) level. Because political boundaries are not ecologically meaningful, biologists often evaluate multi-state bird-environment relationships within one or more Bird Conservation Regions (BCRs). Within North America, BCRs are ecologically unique areas that have similar avian communities and are used to foster a large-scale approach to bird conservation and management (NABCI, 2005). Sauer et al. (2003) examined NABBS data over North America and found BCRs to be useful strata for analyses of avian population trends. Thogmartin et al. (2004a) modelled cerulean warbler (Dendroica cerulea Wilson) abundance as a function of land use and climatic influences in the PrairieHardwood Transition BCR (BCR23). Bird Conservation Regions were also found to be effective strata for mapping predicted abundances of five species of grassland birds as a function of land use and climate variables (Thogmartin et al., 2006). Abundance of American woodcock (Scolopax minor Gmelin) has also shown to be related to landscape habitat variables at varying spatial scales (Thogmartin et al., 2007).

We evaluated the influence of large-scale land-use and climatic variables on waterbird populations in the US portion of Bird Conservation Region 11 (hereafter US-BCR11), the Prairie Pothole Region (PPR). The US-BCR11 of the northern Great Plains is the most important waterfowl habitat in the United States. Modelling wetland species has high applicability to worldwide bird conservation because of the overall decline in these habitats. Similar research can be used in other regions of the world to guide wildlife and habitat management decisions.

We used bird abundance data from the NABBS, land cover data from the National Land Cover Dataset, and climate data from the National Climatic Data Center to model relative waterbird abundance as a function of environmental variables at three different spatial scales. Our objective was to provide models to predict the influence of land use and climatic factors on waterbird populations at a regional scale within US-BCR11. These predictions can be used (1) as a starting point for focusing conservation resources on specific locations where they will be optimally beneficial, and (2) for targeting areas where management strategies for waterbirds will have the most impact.

\section{MATERIALS AND METHODS}

\section{Study area}

Bird Conservation Region 11 (BCR11) covers over $715,000 \mathrm{~km}^{2}$ across five states and three provinces; however, this study examined only the portion within the United States, due to a lack of continuous land cover data across international boundaries (Fig. 1). The general landscape of BCR11 was formed c. 12,000 years ago, when glaciers melted and left behind depressions that collected rain and snow melt (Leitch, 1989). Vegetation composition varies widely across BCR11 due to large fluctuations in hydrological regimes. Submergent vegetation dominates in locations deep enough to have standing water during the dry season. Central zones within 


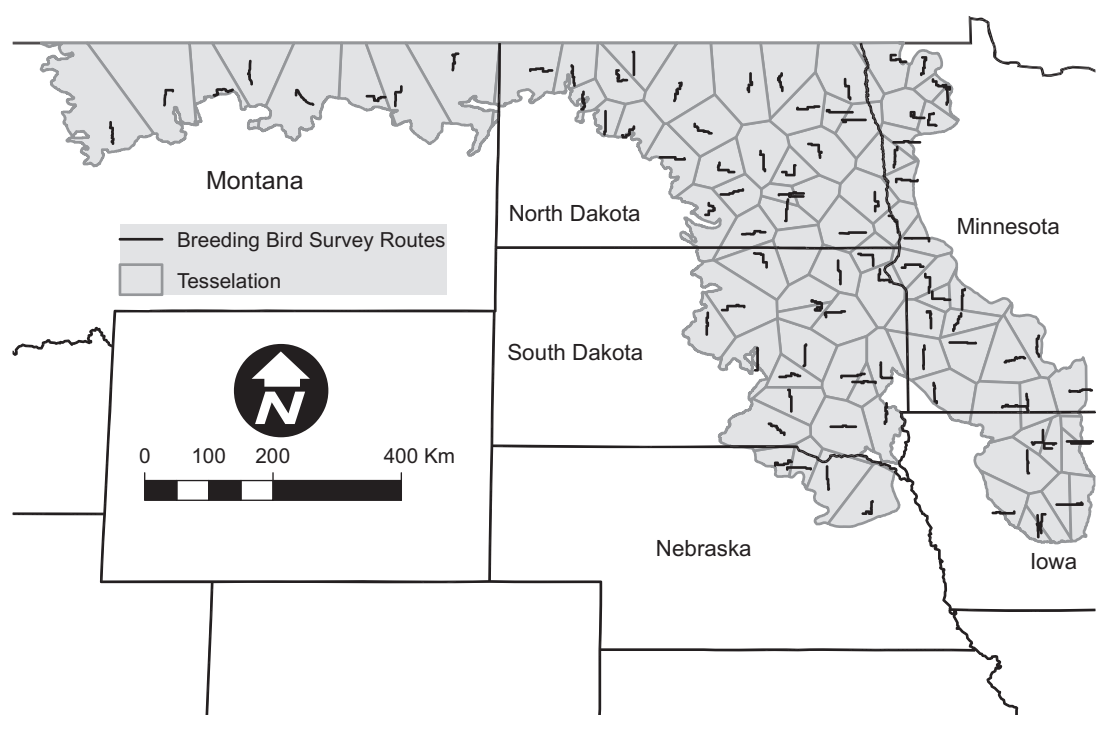

Figure 1 Distribution and tesselation of 95 North American Breeding Bird Survey routes in the US portion of Bird Conservation Region 11. wetlands that periodically dry up contain mid-height and tall emergents. Vernal potholes support primarily grasses, sedges and forbs (Kantrud, 1989). Agriculture is the dominant economic force in BCR11 and has tremendously affected the area ecologically (Euliss et al., 1999). The human population in BCR11 is generally sparse, with people migrating from the rural areas to urban centres as farms increase in size (Leitch, 1989). Increases in urbanization and a concomitant increase in road construction have had a negative impact on the ecology of BCR11 (Euliss et al., 1999). Before European settlement, the region consisted of c. $10 \%$ wetland (Mitsch \& Gosselink, 2000); however, over half of pre-existing wetlands have been drained for agriculture (Leitch, 1989). The remaining wetlands are heavily affected by agriculture-induced sedimentation, large inputs of nutrients, and agricultural chemicals (Euliss et al., 1999).

The climate of BCR11 is characterized by both precipitation and temperature extremes with climate groups B (arid climate) and D (continental climate) from the Köppen climate classification being found in this region. The region is typically colder and wetter to the north and east, and warmer and drier to the west and south, relative to other areas within the region (Kantrud, 1989). Temperatures in BCR11 are generally cold, with mean daily temperatures at or below $0{ }^{\circ} \mathrm{C}$ for 5 months of the year. Air temperatures in the winter can drop below $-60{ }^{\circ} \mathrm{C}$ and can exceed $40{ }^{\circ} \mathrm{C}$ during the summer (Euliss et al., 1999).

\section{Historical data sets}

We assembled data from several existing, large-scale data sets, including bird abundance data from NABBS routes within USBCR11 (Sauer et al., 2006), climate data from the National Climatic Data Center (National Climatic Data Center, 2002), and land cover data from the United States Geological Survey National Land Cover Dataset (US Department of the Interior, Geological Survey, 1992; Vogelmann et al., 2001). We used these data sets in conjunction with a hierarchical spatial count model to predict relative bird abundance as a function of environmental covariates.

The NABBS is a long-term survey effort to monitor the status of bird population trends at a continental scale. Breeding bird survey routes are randomly assigned along roadsides across North America, and are surveyed every year during late May and June. Each route is $39.4 \mathrm{~km}$ in length, and there are 50 stops approximately every $0.8 \mathrm{~km}$ along the route. At each stop, an observer conducts a 3-min point count and records all birds seen or heard within a 402-m radius. Individual routes are surveyed by the same observer each year, when possible, with a consistent method and only under suitable weather conditions (low wind and minimal precipitation). Attempts to minimize variability in NABBS data ensure that data are as unbiased as possible, and that real variation in trends can be detected over time. We used NABBS data between 1980 and 2000 because this time-frame overlaps the time when land cover data were derived from satellite imagery during the early 1990s (Vogelmann et al., 2001). In US-BCR11, there are 95 routes for which data were used in this study (Fig. 1); data from 77 routes were used to create spatial models, while data from 18 randomly selected routes were withheld for validation.

We derived land-use information and metrics from the NLCD 1992 distributed by the United States Geological Survey. Land-use data from the NLCD are available as 30-m grids and represent conditions in the United States in the early 1990s. We evaluated land-use patterns at three spatial scales by creating three sizes of buffer: $0.1 \mathrm{~km}$ (c. $1000 \mathrm{ha}), 1 \mathrm{~km}$ (c. 10,000 ha) and $10 \mathrm{~km}$ (c. 100,000 ha) around each 39.4$\mathrm{km}$ NABBS route. We quantified land-use metrics within each buffer size around each route using ArCGIS v. 9.1 GIS software (ESRI, 2005, Redlands, CA, USA) and Fragstats v. 3.3 (McGarigal et al., 2002). We reclassified National Landcover Data from Anderson Level II classes into a modified Anderson Level I classification (Anderson et al., 1976) to reduce potential errors in land-use classifications that may occur at finer levels. We used raster algebra to multiply the NLCD reclassifications 
with each size of buffer; the resulting grid contained only landuse data within each buffer surrounding each route. We used FRAGSTATS to calculate land-use metrics within each buffer zone surrounding NABBS routes (McGarigal et al., 2002).

We obtained weather data from 245 recording stations from 1980 to 2000 across BCR11 in both the United States and Canada. Data for Canada were used with those from the United States as part of another study to evaluate birdenvironment relationships in the Canadian portion of BCR11 (Forcey et al., 2007). Total precipitation (snowfall combined with rainfall) for stations within the US portion of BCR11 was not provided, so we calculated total precipitation for the United States as follows:

Total precipitation $=$ Rainfall $+(0.1 \times$ Snowfall $)$.

This equation approximates the amount of liquid precipitation as one-tenth of the amount of snowfall, which is a common conversion factor (Akinremi et al., 1999).

We used the kriging function of the Spatial Analyst extension of ArcGIS v. 9.1 (ESRI, 2005) to create a continuous surface for each climate variable from 1980 to 2000 over BCR11. Surface interpolations use information from known points to estimate values on a grid where information is not known. This allowed estimation of climate variables around NABBS routes from the information recorded at surrounding weather stations. We averaged the grid cell values within each $10-\mathrm{km}$ buffer surrounding each NABBS route to compute a value for each weather variable for each route for each year. Resolution of climate interpolations was $1000 \mathrm{~m}$, and all climate variables were evaluated at the largest (100,000-ha) scale.

\section{Modelling approach}

We modelled bird abundance from the NABBS as a function of nuisance effects associated with the survey design, land-use variables and climatic influences using a hierarchical modelling approach within a Bayesian framework. Hierarchical models are useful for modelling NABBS data because they acknowledge correlation among multiple observational units that are present in the survey design. Temporal correlation in counts is present among years and spatial correlation is present among routes. Temporal and spatial correlations occur when count similarity is tied to survey chronology and geographic proximity, respectively. We used a Bayesian framework to fit hierarchical models because all unknown quantities are treated as random variables, and it therefore provides a natural approach to this type of analysis (Link \& Sauer, 2002).

We used Poisson regression to model bird abundance as a function of environmental covariates in US-BCR11 because counts are typically discrete positive values and are often Poisson distributed. Modelling in a Bayesian framework accommodates Poisson-distributed counts, nuisance effects associated with the NABBS, and spatial autocorrelation present in the data. We fitted models using Markov chain Monte Carlo (MCMC) techniques using Gibbs sampling (Link et al., 2002).
Gibbs sampling is an algorithm used to sample the posterior distribution of a random variable (Gelman et al., 2004). We computed three chains for each MCMC simulation with different starting values for each chain to allow computation of the Gelman-Rubin test for convergence (Brooks \& Gelman, 1998). We ran MCMC simulations for 25,000 iterations, including a 20,000-iteration burn-in period required for convergence. Convergence represents the point beyond which the initial values for the chains do not influence the posterior distribution, and dependence on the prior distribution is minimized. We used WinBUGS v. 1.4.1, which provides a means to run MCMC simulations using Gibbs sampling (Spiegelhalter et al., 2003).

We used data from 1212 NABBS counts surveyed by 145 observers from 1980 to 2000 to model bird abundance as a function of environmental covariates in US-BCR11. The response variable in the models is the total number of birds for each species across the entire route for each year. We incorporated nuisance effects into the model at three levels in the hierarchy. We included a random year effect and a fixed effect trending term to account for inherent temporal variation in bird abundance occurring as populations fluctuate naturally (Link \& Sauer, 2002). We included two observer effects in the model: one random effect accounted for differences in surveying abilities among observers (Sauer et al., 1994) and the other fixed effect accounted for inexperience (a first-time observer effect). The first-time observer effect was a binary variable which was 0 if it was an observer's first time surveying a given route and a 1 if the observer had surveyed the route previously. The first-time effect accounted for improvements in observer bird identification over time, increased surveying efficacy, and associating certain species with individual stops (Kendall et al., 1996). We accounted for spatial autocorrelation in counts with a spatial conditional autoregressive (CAR) prior distribution on the route random effect (Banerjee et al., 2004). We derived an adjacency matrix (Lawson et al., 2003) within US-BCR11 from an irregular lattice created from a tessellation of NABBS routes within BCR11 (Hooge \& Eichenlaub, 1997) (Fig. 1). Spatial autocorrelation is accounted for when routes share a common boundary in the tessellation; distances among routes are not taken into account, although this is possible in other applications (Su et al., 2004).

The final model we used has the form:

$$
\log [\lambda(s)]=\sum_{k=1}^{n} v_{k}(s)+Z_{k}(s)+\omega_{k}(s)+\eta I(s)+\gamma_{k}(s)+\varepsilon_{k} .
$$

Lambda $(\lambda)$ represents the count of a species on a route for a given year (sample size $k=1$ to $n$ ). Counts, environmental covariates and nuisance effects all occurred across space $(s) . v_{\mathrm{k}}$ describes a matrix of environmental fixed effects $(x)$ and their associated parameters $(\beta)$. One unique aspect of Bayesian analyses is the inclusion of prior beliefs or information that may influence the final outcome. This prior information (henceforth 'priors') can be either vague or specific. Because little information is known about how environmental variables influence waterbirds at the regional level, we assigned vague 
prior distributions to parameters in the model (Link \& Sauer, 2002). Year $(\gamma)$ and observer $(\omega)$ were treated as random effects, with mean zero normal distributions; beta parameters and novice effects $(\eta)$ were given normal distributions with mean of 0 and variance equal to 1000 (Link \& Sauer, 2002; Thogmartin et al., 2004a). Spatial effects $(Z)$ were modelled as a conditional autoregressive normal prior. This hierarchical spatial count model was used by Thogmartin et al. (2004a, 2006) to model the effects of environmental covariates on cerulean warblers and five grassland bird species. Overdispersion was accommodated via a normal random effect on the observation level with a diffuse variance prior distributed uniformly between 0.001 and 1000 .

The number of environmental variables that can be measured through remote sensing is large relative to our sample size. Because of risks associated with finding spurious effects when examining a large number of covariates, variables that were thought to be important descriptors of bird abundance were selected a priori. We reviewed published habitat associations and life histories for waterbirds in this study to determine which environmental variables would be likely to have the largest effects on abundance (Table 1). These variables were used to construct a candidate set of models at each spatial scale for each focal species. Spearman's rank correlations were calculated for environmental covariates; covariates with a correlation coefficient $>0.5$ were not included in the same a priori model.

Life history was evaluated for mallard (Drilling et al., 2002), blue-winged teal (Anas discors Linnaeus) (Rohwer et al., 2002), ruddy duck (Oxyura jamaicensis Gmelin) (Brua, 2002) and pied-billed grebe (Podilymbus podiceps Linnaeus) (Muller \& Storer, 1999). These species were chosen for the following reasons: (1) this group of species represented a variety of waterbirds with copious data available on spatial distribution and abundance; (2) these species are abundant and conspicuous, which makes them conducive to representation by the NABBS - having a strong data set is important for evaluating new modelling approaches; (3) these species can be important indicators of the overall health of the Prairie Pothole ecosystem given their wide distribution in this area; and (4) these species occur in a variety of different habitats with mallard and bluewinged teal preferring seasonal wetlands, and pied-billed grebe and ruddy duck preferring more permanent wetlands (Johnson \& Grier, 1988).

We standardized all environmental variables to have a mean of 0 and standard deviation of 1 . This not only improves MCMC convergence (Gilks \& Roberts, 1996), but also allows comparison of the slopes in the model to assess the relative importance of each variable. We constructed models with covariates at a common scale; we did not have sufficient $a$ priori information available to warrant constructing multiscale models.

We ranked models as to how well they fit the data by comparing the deviance information criterion (DIC) among models and ranking them, within each of the three scales, accordingly (Spiegelhalter et al., 2002). We constrained infer- ence to models that were within 4 DIC units of the best model, which approximates a 95\% confidence set of best models (Burnham \& Anderson, 2002, p. 170). We calculated model weights and variable importance measures to assess the relative importance of each model and variable, respectively. We also modelled null models (which contained no environmental variables, only nuisance variables associated with the survey design) to provide a reference point to ascertain the degree to which environmental variables improved model fit.

After completing model fitting of the models identified $a$ priori, we conducted post-hoc analyses to determine if other variables and models provided a better fit to the data. We evaluated slope coefficients and 95\% credibility intervals from explanatory variables in the a priori candidate models to determine the relative strength of association for each variable. We created several additional models for each species, using variables whose $95 \%$ credibility interval did not overlap zero; the $95 \%$ credibility intervals were based on models from the $a$ priori candidate set. This allowed exploration of additional models that might provide a better fit to the data but which were not identified a priori. We included models identified post hoc that had a lower DIC value than the best a priori model.

\section{Model evaluation}

We withheld data from 18 NABBS routes in BCR11 from model construction so that known abundance information from these routes could be compared with estimated abundances generated from the best model. We assessed the model against independent (or external) data by regressing observed data against imputed (expected) values derived from the final mapped model (Thogmartin et al., 2007). The observed data were data randomly withheld from the modelling process ( $n=257$ counts). This imputation was consistent with the data and priors, and was conditional on the values of the model parameters. We compared abundance values calculated for withheld routes with known data using simple linear regression. We evaluated our models using two aspects of model validation: discrimination and calibration. We compared the ability of the model to predict abundance by comparing the slopes of the regression line to a $1: 1$ correspondence line (calibration) and by examining the $R^{2}$ values of the regression line (discrimination). All regression analyses were performed using the $\mathrm{R}$ stats package (R Development Core Team, 2007).

\section{Relative abundance mapping}

We created spatial maps of bird abundance across US-BCR11 for each waterbird species in this study. Spatial models were based on model-averaged beta parameters in each model within the subset of best models (Burnham \& Anderson, 2002, p. 151). We standardized data layers in the GIS before creating maps of bird abundance because the same covariates were standardized prior to MCMC simulation. We mapped waterbird abundance by creating three sizes of regular lattices over 
Table 1 A priori environmental variables included in suites of candidate models predicting waterbird abundance in the US portion of Bird Conservation Region 11 for each species modelled. All covariates were standardized with a mean of 0 and standard deviation of 1 .

\begin{tabular}{|c|c|c|c|}
\hline Type of variable & Variable & Variable description & Species modelled ${ }^{*}$ \\
\hline \multirow[t]{6}{*}{ Climate } & Previous year precipitation & $\begin{array}{l}\text { Total precipitation from the year prior to when } \\
\text { bird abundance was measured }\end{array}$ & All species \\
\hline & Previous spring temperature & $\begin{array}{l}\text { Mean spring temperature (March-June) from } \\
\text { the spring prior to when bird abundance was } \\
\text { measured }\end{array}$ & All species \\
\hline & Yearly precipitation & $\begin{array}{l}\text { Total precipitation from the same year bird } \\
\text { abundance was measured }\end{array}$ & All species \\
\hline & Yearly temperature & $\begin{array}{l}\text { Mean yearly temperature from the same year } \\
\text { bird abundance was measured }\end{array}$ & All species \\
\hline & Spring precipitation & $\begin{array}{l}\text { Total spring (March-June) precipitation from } \\
\text { the same year that bird abundance was } \\
\text { measured }\end{array}$ & All species \\
\hline & Spring temperature & $\begin{array}{l}\text { Mean spring temperature from the same year } \\
\text { bird abundance was measured }\end{array}$ & All species \\
\hline \multirow[t]{8}{*}{$\begin{array}{l}\text { Patch-level land } \\
\text { cover }\end{array}$} & Developed (\%) & $\begin{array}{l}\text { Percentage of developed area in the landscape } \\
\text { (includes roads, buildings, etc.) }\end{array}$ & \\
\hline & Forest $(\%)$ & $\begin{array}{l}\text { Percentage of tree cover in the landscape } \\
\text { (includes deciduous and coniferous trees) }\end{array}$ & RUDU \\
\hline & Herbaceous planted (\%) & $\begin{array}{l}\text { Percentage of herbaceous planted in the } \\
\text { landscape (includes cropland, fallow, and, } \\
\text { pasture) }\end{array}$ & MALL, BWTE \\
\hline & Herbaceous upland (\%) & $\begin{array}{l}\text { Percentage of herbaceous planted in the } \\
\text { landscape (includes grasses and forbs) }\end{array}$ & MALL, BWTE \\
\hline & Water $(\%)$ & Percentage of open water in the landscape & All species \\
\hline & $\begin{array}{l}\text { Water interspersion and } \\
\text { juxtaposition index } \dagger\end{array}$ & $\begin{array}{l}\text { Percentage of land-use types that are adjacent } \\
\text { to open water }\end{array}$ & BWTE, RUDU, PBGR \\
\hline & Water largest patch index (\%) & $\begin{array}{l}\text { Percentage of total landscape comprised by the } \\
\text { largest patch of open water }\end{array}$ & PBGR \\
\hline & Wetland (\%) & Percentage of vegetated wetland in the landscape & All species \\
\hline \multirow[t]{3}{*}{$\begin{array}{l}\text { Landscape-level } \\
\text { land cover }\end{array}$} & $\begin{array}{l}\text { Wetland interspersion and } \\
\text { juxtaposition index } \dagger\end{array}$ & $\begin{array}{l}\text { Percentage of land-use types that are adjacent to } \\
\text { vegetated wetland }\end{array}$ & MALL, PBGR \\
\hline & Contagion $\S$ & $\begin{array}{l}\text { Aggregation of different patch types in the } \\
\text { landscape (low contagion indicates many land } \\
\text { uses in the landscape) }\end{array}$ & MALL, RUDU, PBGR \\
\hline & Simpson's diversity & Diversity of land uses in the landscape & MALL, BWTE \\
\hline
\end{tabular}

${ }^{*}$ Species abbreviations: MALL = mallard (Anas platyrhynchos), BWTE = blue-winged teal (Anas discors), RUDU = ruddy duck (Oxyura jamaicensis), PBGR = pied-billed grebe (Podilymbus podiceps).

$\dagger$ Interspersion and juxtaposition index is when a particular land-use type is adjacent to only one other land-use type. Interspersion and juxtaposition index equals 100 when a particular land-use type is equally adjacent to all other land-use types. The interspersion and juxtaposition index equals minus the sum of the length $(\mathrm{m})$ of each unique edge type involving the corresponding patch type divided by the total length ( $\mathrm{m}$ ) of edge $(\mathrm{m})$ involving the same type, multiplied by the logarithm of the same quantity, summed over each unique edge type; divided by the logarithm of the number of patch types minus 1; multiplied by 100 (to convert to a percentage) (McGarigal et al., 2002).

$\$$ Largest patch index equals the area of the largest patch of a particular land use divided by the total landscape area, multiplied by 100 .

$\$$ Contagion is when every grid cell is a different land-use type. The contagion index equals 100 when the landscape consists of a single land-use type. This metric is similar to interspersion and juxtaposition except that contagion is based on cell adjacencies and not land-use type adjacencies.

- Simpson's diversity index represents the chance that any two grid cells selected at random would be different land-use types.

US-BCR11; the three sizes correspond to the spatial extents examined in the study (1000, 10,000 and 100,000 ha). For each bird species, we summarized environmental covariates using a lattice size that equals the scale(s) at which each covariate was determined to be important. Final maps of avian abundance had a 1000-m resolution and all mapping operations were computed using the raster calculator in the Spatial Analyst extension of ArcGIS v. 9.1 (ESRI 2005).

\section{RESULTS}

Both landscape and climatic factors were important descriptors of waterbird abundance in US-BCR11 (see Table 2 and Appendix S1 in Supporting Information). The influence of scale was less pronounced, as models with the same predictor variables at different scales had similar DIC values for many species (Table 2, Appendix S1). Slope coefficients for the same 


\section{G. M. Forcey et al.}

Table 2 Explanatory variables and the scale at which they were evaluated from the best models for each bird species studied in the US portion of Bird Conservation Region 11: mallard (Anas platyrhynchos), blue-winged teal (Anas discors), ruddy duck (Oxyura jamaicensis) and pied-billed grebe (Podilymbus podiceps).

\begin{tabular}{|c|c|c|c|c|c|c|c|}
\hline Species & Model $^{1}$ & $\begin{array}{l}\text { Scale } \\
(\text { ha })^{2}\end{array}$ & Parameters $^{3}$ & $\mathrm{DIC}^{4}$ & $\Delta \mathrm{DIC}^{5}$ & $w_{i}^{6}$ & $\begin{array}{l}\text { Evidence } \\
\text { ratio }^{7}\end{array}$ \\
\hline \multirow[t]{2}{*}{ Mallard } & $\begin{array}{l}\text { YearPrecip + YearTemp + } \\
\text { WetlandInterspersionJuxtaposition + Contagion }\end{array}$ & 100,000 & 730.284 & 5001.22 & 0 & 0.09 & 1.00 \\
\hline & Null & & 732.468 & 5006.69 & 5.47 & & \\
\hline \multirow[t]{2}{*}{ Blue-winged teal } & $\begin{array}{l}\text { SpringPrecip + SpringTemp + Water }(\%)+ \\
\text { Wetland }(\%)+\text { SimpsonsDiversity }\end{array}$ & 100,000 & 512.371 & 3339.17 & 0 & 0.16 & 1.00 \\
\hline & Null & & 514.007 & 3345.73 & 6.56 & & \\
\hline \multirow[t]{2}{*}{ Ruddy duck } & $\begin{array}{l}\text { YearPrecip + YearTemp + Water(\%)+ } \\
\text { Wetland }(\%)+\text { Forest }(\%)\end{array}$ & 1000 & 210.429 & 1174.21 & 0 & 0.24 & 1.00 \\
\hline & Null & & 213.811 & 1184.23 & 10.02 & & \\
\hline \multirow[t]{2}{*}{ Pied-billed grebe } & YearPrecip + YearTemp & 100,000 & 277.232 & 1700.47 & 0 & 0.46 & 1.00 \\
\hline & Null & & 281.09 & 1710.88 & 10.41 & & \\
\hline
\end{tabular}

The null model (a model without any environmental covariates) was included to serve as a comparison with the best models that contain environmental variables. Precipitation variables were modelled at the largest (100,000-ha) scale.

${ }^{1}$ Descriptions of model parameters can be found in Table 1. No best models were found using the post-hoc analysis.

${ }^{2}$ The scale at which the variable was measured is presented in hectares. Null models have no scale associated with them.

${ }^{3}$ The effective number of parameters is calculated by the posterior mean of the deviance minus the deviance of posterior means.

${ }^{4}$ Deviance information criterion.

${ }^{5} \Delta \mathrm{DIC}$ is the DIC difference between the best model and the model for which the $\Delta \mathrm{DIC}$ is given.

${ }^{6}$ Model weights provide a measure of support for the model relative to the others in the table and are calculated with the following equation, where $\Delta_{i}$ and $\Delta_{r}$ are the $\Delta$ DIC values for each model (Burnham \& Anderson, 2002, p. 75).

$w_{i}=\frac{\exp \left(-\frac{1}{2} \Delta_{i}\right)}{\sum_{r=1}^{R} \exp \left(-\frac{1}{2} \Delta_{r}\right)}$

${ }^{7}$ Evidence ratio is calculated by dividing the $w_{i}$ for the best model by the $w_{i}$ for the model which the evidence ratio applies.

variable across scales were generally similar, further indicating a lesser importance of landscape scale (Appendix S2). Climate variables contributed strongly to predicting bird abundance for all species. No candidate models in the best subset for any species lacked climate variables, and candidate models without climate covariates had higher DIC values than models with climate predictors. We considered a variable as having a strong effect if its $95 \%$ credibility interval did not overlap with zero. Wetland area was also a strong covariate across most species, and all species were positively associated with this variable. Post-hoc analyses did not reveal any models with better fit than a priori models (Table 2, Appendix S1). Most other variables (with the exception of wetland variables) were not strongly related with abundance of waterbirds in US-BCR11.

Model selection uncertainty was high for mallards, with 20 models within four DIC units of the best model, and the best model having a weight of 0.09 (Table 2, Appendix S1). The most important environmental predictors of mallard abundance were yearly precipitation, current-year spring precipitation, water area, wetland area and contagion. In general, mallards were most influenced at the coarsest scales, but model selection uncertainty limited the ability to make a definitive conclusion (Appendix S2). Predicted maps of abundance showed mallards to be most abundant in central North Dakota and north-eastern South Dakota. Small areas in north central Montana also were predicted to contain high numbers of mallards (Fig. 2a).
Models explaining blue-winged teal abundance also showed uncertainty, with 14 models in the best subset (Table 2, Appendix S1). Both spring temperature and spring precipitation were strongly related to blue-winged teal abundance (Appendix S2). Wetland area was also an important covariate across the finest and intermediate scale, but its relationship with abundance was negligible at the coarsest scale. Both current-year spring temperature and current-year spring precipitation were also important predictors of abundance, with strong negative and positive relationships, respectively (Appendix S2). The predicted abundance map for blue-winged teal showed abundances to be highest in central North Dakota and north central South Dakota, with lower abundances elsewhere in US-BCR11 (Fig. 2b).

Ruddy ducks showed a smaller degree of model uncertainty than the other waterfowl, with the best model weighted at 0.24 , and 11 candidate models competing with the best model. The influence of scale was more pronounced with this species, with only covariates at the finest and intermediate scale appearing in the best subset of models (Table 2, Appendix S1). Ruddy duck abundance was related to current year, previous year, and spring precipitation variables. The relationship with temperature variables was negligible. Land cover predictors associated with ruddy duck abundance included total area of water and wetland at the finest and intermediate scales; the influence of these variables at the coarsest scale was much smaller (Appendix S2). The mapped 
(a)

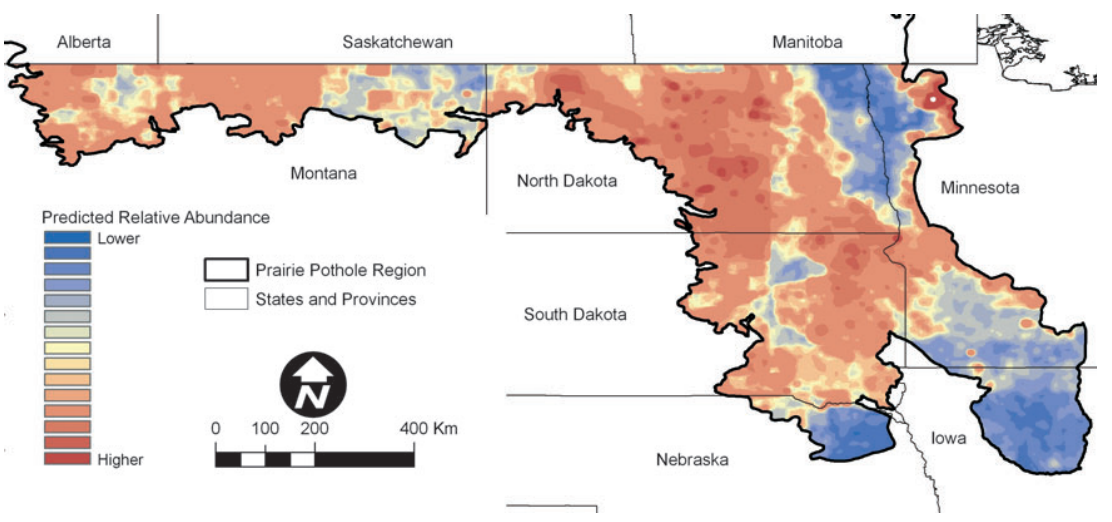

(b)

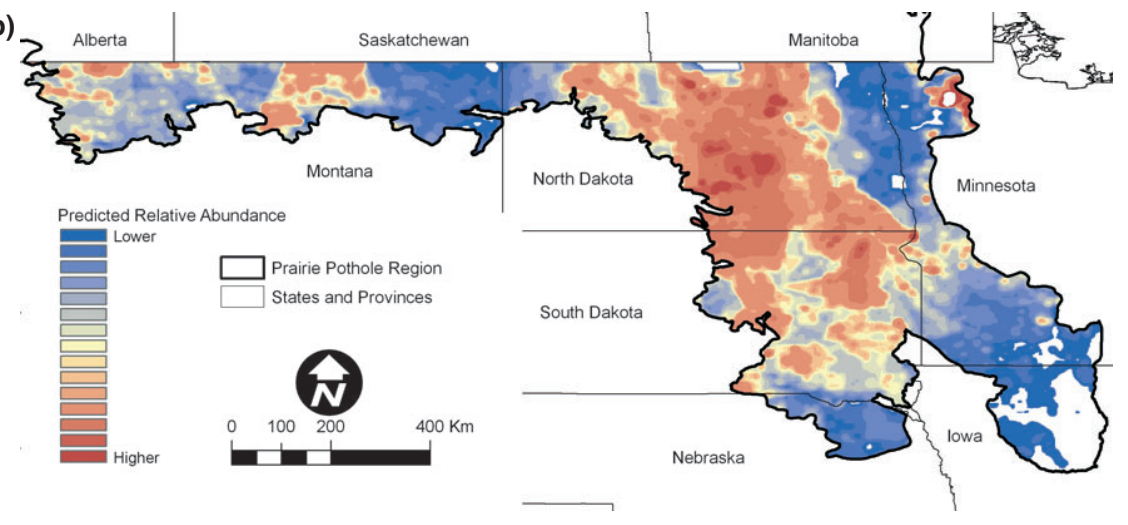

(c)

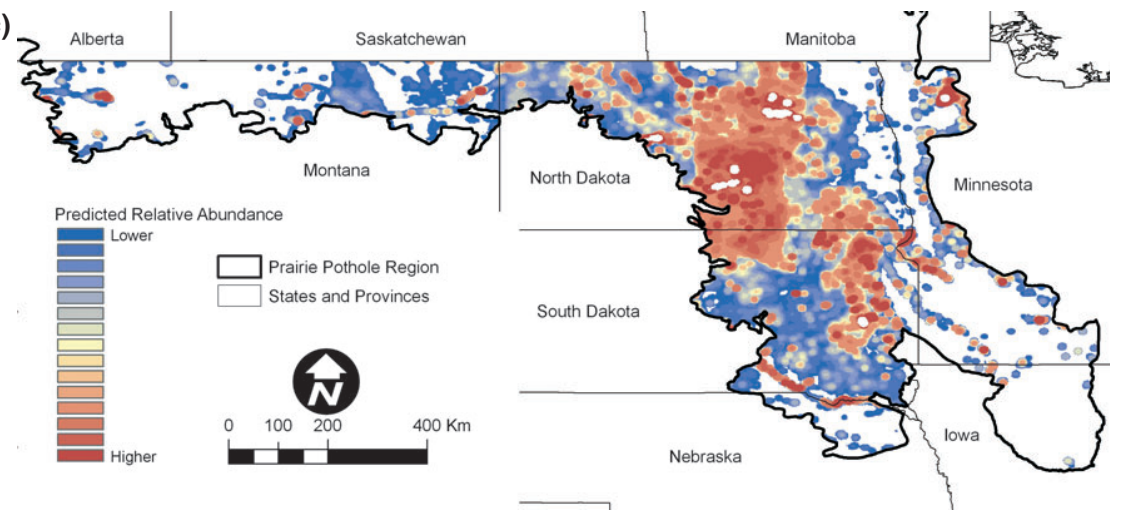

(d)

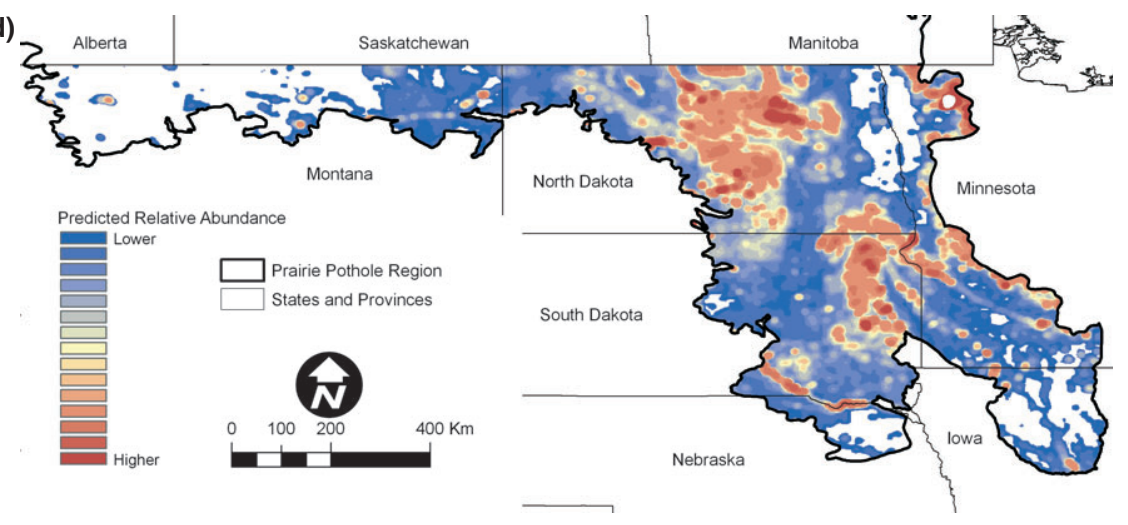

Figure 2 Predicted relative abundance for (a) mallard (Anas platyrhynchos), (b) blue-winged teal (Anas discors), (c) ruddy duck (Oxyura jamaicensis), (d) pied-billed grebe (Podilymbus podiceps) in the US portion of Bird Conservation Region 11, the Prairie Potholes. Different shades should only be treated as a difference in predicted relative abundance within a species. Mapping was performed using model-averaged values (Burnham \& Anderson, 2002). 
model showed ruddy ducks to be most concentrated in south central North Dakota and north central South Dakota (Fig. 2c).

Model selection uncertainty was low for pied-billed grebes, with the best model weighted at 0.46 (Table 2, Appendix S1). Pied-billed grebes were correlated with many environmental covariates depending on the scale of the analyses. Water area had the strongest relationship at the intermediate scale. The most important climate predictors were spring and yearly precipitation in the current year (Appendix S2). The predicted abundance map for pied-billed grebes showed scattered high concentrations of abundance to occur in central North Dakota and north-eastern South Dakota, with lower abundances occurring elsewhere in US-BCR11 (Fig. 2d).

\section{Model validation}

In general, validation through discrimination showed that models predicting waterbird abundance in US-BCR11 had moderate to good fit $\left(R^{2}=0.23-0.51\right)$. The calibration component of our validation showed that models generally overpredicted bird numbers for ruddy duck, under-predicted abundance for pied-billed grebe, and equally under- and overpredicted for blue-winged teal and mallard (Fig. 3). The model
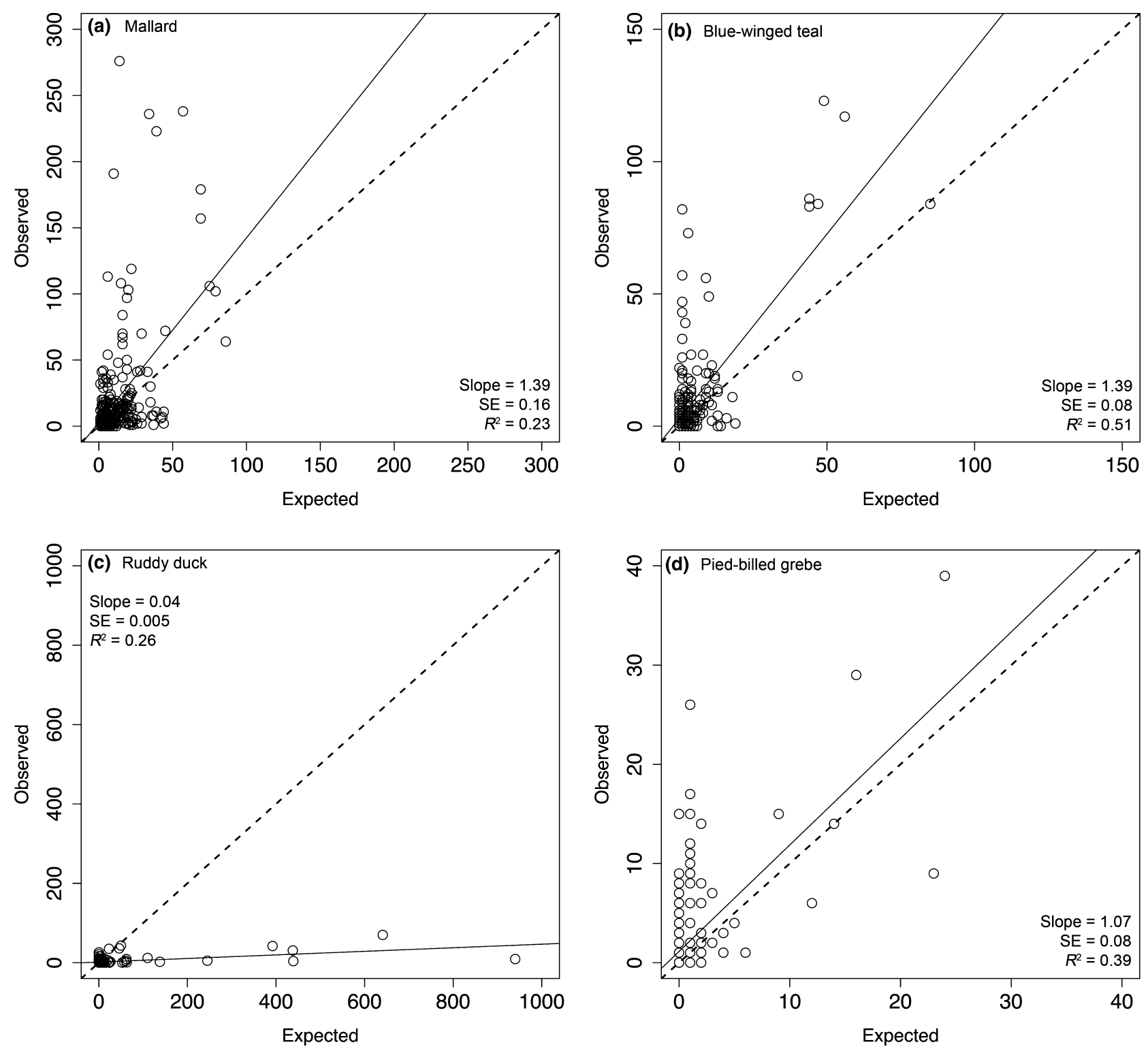

Figure 3 Simple linear regression plots validating spatial models for predicting bird abundance in the US portion of Bird Conservation Region 11 ( $n=257, P<0.001$ for all species): (a) mallard (Anas platyrhynchos), (b) blue-winged teal (Anas discors), (c) ruddy duck (Oxyura jamaicensis), (d) pied-billed grebe (Podilymbus podiceps). The solid line represents the regression line; the dotted line represents a 1:1 correspondence line. Validation was done using values generated from the best model from each species (Table 2). 
grossly over-predicted (by 200-1000 birds) abundances for nine counts for ruddy ducks on a single route in North Dakota (route 18), but performed well for the remainder of counts.

\section{DISCUSSION}

Hierarchical spatial count modelling showed relationships between waterbird abundance and large-scale land-use and climate variables. Most focal species were related to both land cover and climatic variables at all three spatial extents. Overall, no particular spatial extent had a predominant association with bird abundance, although some species (i.e. ruddy duck) did not show correlations with one of the three scales. Although spatial scale has been shown to be important in other studies (Pribil \& Picman, 1997; Saab, 1999; Holland et al., 2004), it may be unimportant for most waterbird species in US-BCR11 for one or more of the following reasons: (1) the scales used in these analyses do not correspond to the scales at which waterbirds respond to environmental variables; (2) smaller-scale effects are driving waterbird abundance; or (3) errors in climate interpolations or land-use data may preclude the ability to detect the effects of scale that we examined.

We included wetland area as a covariate a priori in all candidate models because all focal species use wetlands to some extent in US-BCR11. Our hypotheses regarding positive relationships with wetland area were largely confirmed, with all species showing a positive association with this variable at one or more scales (Appendix S2).

Including climate predictors in models made notable improvements in model fit for all species. All candidate models for each species in the best subset included at least one climate variable, indicating that climate predictors are important for describing bird abundance in US-BCR11. This finding concurs with other studies, including that of Venier et al. (2004), who found that adding climate variables to models with land cover covariates improved fit. Cotgreave (1995) also noted strong relationships between temperature and precipitation variables and bird abundance patterns, and Root (1988) revealed strong correlations between bird distributions and temperature and precipitation variables. Climate effects found in the present study may have been more pronounced because of the additional information present in time-series data as opposed to data averaged across many years.

Mallards, blue-winged teal, ruddy ducks and pied-billed grebe show strong relationships with the presence of wetland habitat at large scales in US-BCR11. This result was anticipated given the foraging requirements for waterfowl and corroborating evidence from other studies (Mulhern et al., 1985; Krapu et al., 2000; Miller, 2000). Given the importance of wetlands, it is not surprising that precipitation variables were strongly associated with mallard and blue-winged teal abundance. Strong positive relationships between herbaceous vegetation at the finest scale and mallard and blue-winged teal abundance were confirmed in this analysis, and were probably due to these species preferring areas with good nesting cover (Drilling et al., 2002; Rohwer et al., 2002).
Relationships between mallard and blue-winged teal and herbaceous cover may also be apparent due to philopatry of successfully nesting females and their offspring (Arnold \& Clark, 1996). A negative relationship between the previous year's spring temperature and blue-winged teal abundance was contrary to what was hypothesized a priori. Colder temperatures often negatively affect recruitment of waterfowl; however, mallards and blue-winged teal do not appear to be adversely affected by colder spring temperatures in US-BCR11. Miller (2000) also showed that abundance of mallard in the USBCR11 region is less related to temperature than that of those nesting in other biomes.

Ruddy ducks and pied-billed grebes were positively associated with increasing precipitation, and ruddy ducks were more associated with precipitation variables in the current year rather than in the previous year. The floating platform nests used by pied-billed grebes (Muller \& Storer, 1999) may make them more reliant on recent local precipitation amounts than other waterbirds in this study. However, pied-billed grebes nest earlier than ruddy ducks and often use old vegetation as nesting substrate. This behaviour suggests that precipitation from the previous year should have had more influence on this species than that from the current year. Pied-billed grebe abundance was also related to water and wetland amounts at the intermediate scale, which can be explained by their tendency to remain within close proximity of nesting wetlands (Naugle et al., 1999). Strong associations with water area and wetland area also occurred for ruddy ducks, which is likely to be due to their preference for large wetlands (Brua, 2002); inhabiting large wetlands may make this species less dependent on habitat further from their territory. The inverse relationship between the contagion index and pied-billed grebe abundance (though weak) can be explained by its affinity for multiple land cover types (wetlands, water and agricultural fields) around the nesting area (Muller \& Storer, 1999). Savard et al. (1994) showed that ruddy ducks prefer wetlands surrounded by few trees, a relationship confirmed in our study by a negative association between ruddy ducks and total forest.

Technical limitations, inherent with remote sensing, reduce our ability to clarify relationships between waterbird abundance and environmental covariates at the regional scale. For example, water depth, an important influence on the presence of diving ducks (Murkin et al., 1997), cannot be measured by remote sensing. Further, spatial data on the annual changes in areal coverage of emergent vegetation, which provides nest substrate and cover for waterbirds (Linz et al., 1996), are not available. Another issue with land-use data involves classification errors, which can occur during image interpretation. Some cover types, especially rare ones, may be incorrectly classified or overlooked completely when digitizing Thematic Mapper data (Thogmartin et al., 2004b). We have attempted to reduce classification inaccuracies by reclassifying the NLCD 1992 into broader land-use categories similar to the Anderson level 1 classification system (Anderson et al., 1976), thereby increasing classification accuracy. Forcey et al. (2007) found little influence of land-use variables on bird abundance in 
Canada, while many strong relationships occurred in our study. We do not attribute this to ecological differences between the two countries, but rather to differences in land-use data thematic and spatial resolution. The availability of $30-\mathrm{m}$ resolution data for the United States made it possible to reveal large-scale relationships with land-use variables that were not possible with the $100-\mathrm{m}$ resolution data available from Canada.

Possible errors in our climate interpolations may have reduced our ability to find climate relationships with waterbirds. These errors are most pronounced in locations with low densities of weather-recording stations and at small scales. Because of our large sample of weather-recording stations $(n=245)$, we suggest that large-scale errors over US-BCR11 are unlikely and that micro-variation in climate variables at small scales is not relevant for regional-scale modelling efforts. A final concern with our modelling approach involves using time-series climate data with static land cover data. The lack of time series land cover data reduces the amount of information present and prevents evaluation of how bird populations respond to land cover change over time. This issue could be exacerbated in US-BCR11 due to the addition of CRP (conservation reserve program) land in this area from 1980 to 2000. In our model, changes in land cover over the times series of the response would be accommodated in the random effect associated with years. Incorporation of time-series land cover and water cover data would probably improve the ability to detect effects of these variables on waterbird populations as the two interact over time. Even so, we were able to elucidate the effects of land cover on waterbirds in US-BCR11, and the strength of these effects were, in some instances, greater than those of climatic influences.

Results from both discrimination and calibration validation show models generally predicted the withheld data well $\left(R^{2}=0.23-0.51\right)$, although there were exceptions. Although some models fitted the data less well, we believe that mapping the models is useful as long as the results from model validations are considered when interpreting the maps. Models grossly over-predicted abundances for ruddy ducks for nine counts on route 18 in north-central North Dakota. North Dakota route 18 is surrounded by a disproportionate amount of wetland area at the finest and intermediate scales compared with other routes in US-BCR11. Given the strength of association of these variables with ruddy ducks (Appendix S2), the model over-predicted abundance of this species on this NABBS route. While the model over-predicted the raw number of birds, the observed numbers on this route were in the upper range of abundances recorded for these species. Removing North Dakota route 18 predictions did not significantly improve the model fit. This suggests that, while estimated raw numbers of birds may be unreliable in some cases or areas, the models still predicted accurate patterns in relative abundance. Maps of relative abundance for waterbirds in US-BCR11 should be interpreted with this caveat in mind and should be used only when evaluating relative abundance of waterbirds across a region such as US-BCR11. Abundance maps should be supplemented with ancillary field data before any conservation or management decisions are made, in order to validate the presence and relative abundance of the waterbird species of concern.

\section{MANAGEMENT IMPLICATIONS}

With conversion of wetlands and grasslands into agriculture over large areas, conservation of birds in large ecoregions will continue to remain a priority for biologists and land managers. Application of our models to waterbird conservation and management serves two purposes: (1) models provide information on how waterbirds are related to climate and land-use patterns at varying spatial scales, and (2) maps of predicted relative abundance suggest locations where conservation and management efforts should be focused in order to have most benefit on habitats favouring the species of interest. Obviously, climate cannot be managed, but it is possible to manage landuse patterns to aid in the conservation and management of waterbirds in large ecoregions throughout the world. Furthermore, understanding the relationships of these waterbirds to climate may allow predictions of the effects of climate change on future patterns of distribution and abundance.

\section{ACKNOWLEDGEMENTS}

We thank M. Biondini, G. Clambey and G. Nuechterlein for their contributions and advice on this study. D. Anderson, D. Granfors, R. Johnson, N. Niemuth and J. Sauer provided suggestions on the data analyses for this project. We also thank E. O'Neal for providing ArcGIS plug-ins to simplify the spatial analyses of climate and land-use data. We are grateful to the thousands of volunteers who annually conduct breeding bird survey counts. This project was funded by the National Wildlife Research Center, a unit within the United States Department of Agriculture, Animal Plant and Health Inspection Service, Wildlife Services. G. Linz was the Study Director. Financial support was also provided by the Department of Biological Sciences and the Graduate School at North Dakota State University.

\section{REFERENCES}

Akinremi, O.O., McGinn, S.M. \& Cutforth, H.W. (1999) Precipitation trends on the Canadian prairies. Journal of Climate, 12, 2996-3003.

Anderson, J.R., Hardy, E.E., Roach, J.T. \& Witmer, R.E. (1976) A land use and land cover classification system for use with remote sensor data. US Department of the Interior, Geological Survey, Geological Survey Professional Paper 964. United States Government Printing Office, Washington, DC.

Arnold, T.W. \& Clark, R.G. (1996) Survival and philopatry of female dabbling ducks in southcentral Saskatchewan. Journal of Wildlife Management, 60, 560-568.

Banerjee, S., Carlin, B.P. \& Gelfand, A.E. (2004) Hierarchical modeling and analysis of spatial data. Monographs on 
Statistics and Applied Probability, Vol. 101. Chapman \& Hall/CRC, Boca Raton, FL.

Brooks, S.P. \& Gelman, A. (1998) Alternative methods for monitoring convergence of iterative simulations. Journal of Computational and Graphical Statistics, 7, 434-455.

Brua, R.B. (2002) Ruddy duck (Oxyura jamaicensis). The birds of North America online (ed. by A. Poole and F. Gill). Academy of Natural Sciences, Philadelphia and American Ornithologists' Union, Washington, DC. Available at: http://bna.birds.cornell.edu.bnaproxy.birds.cornell.edu/bna/ species/696 (accessed 10 April 2011).

Burnham, K.P. \& Anderson, D.R. (2002) Model selection and multimodel inference: a practical information-theoretic approach, 2nd edn. Springer-Verlag, New York.

Calder, C., Lavine, M., Muller, P. \& Clark, J.S. (2003) Incorporating multiple sources of stochasticity into dynamic population models. Ecology, 84, 1395-1402.

Clark, R.G. \& Weatherhead, P.J. (1986) The effect of fine-scale variations in agricultural land use on the abundance of redwinged blackbirds. Canadian Journal of Zoology, 64, 19511955.

Cotgreave, P. (1995) Weather conditions are correlated with the relation between mass and abundance in bird communities. Acta Oecologica, 16, 543-552.

Cushman, S.A. \& McGarigal, K. (2002) Hierarchical, multiscale decomposition of species-environment relationships. Landscape Ecology, 17, 637-646.

Drilling, N., Titman, R. \& McKinney, F. (2002) Mallard (Anas platyrhynchos). The birds of North America online (ed. by A. Poole and F. Gill). Academy of Natural Sciences, Philadelphia and American Ornithologists' Union, Washington, DC. Available from: http://bna.birds.cornell.edu.bnaproxy.birds. cornell.edu/bna/species/658 (accessed 10 April 2011).

Euliss, N.H., Jr, Mushet, D.M. \& Wrubleski, D.A. (1999) Wetlands of the Prairie Pothole Region: invertebrate species composition, ecology, and management. Invertebrates in freshwater wetlands of North America: ecology and management (ed. by D.P. Batzer, R.B. Rader and S.A. Wissinger), pp. 471-514. John Wiley \& Sons, New York.

Fairbairn, S.E. \& Dinsmore, J.J. (2001) Local and landscapelevel influences on waterbird communities of the Prairie Pothole Region of Iowa, USA. Wetlands, 21, 41-47.

Flather, C.H. \& Sauer, J.R. (1996) Using landscape ecology to test hypotheses about large-scale abundance patterns in migratory birds. Ecology, 77, 28-35.

Forcey, G.M., Linz, G.M., Thogmartin, W.E. \& Bleier, W.J. (2007) Influence of land use and climate on wetland breeding birds in the Prairie Pothole Region of Canada. Canadian Journal of Zoology, 85, 421-436.

Gelman, A., Carlin, J.B., Stern, H.S. \& Rubin, D.B. (2004) Bayesian data analysis, 2nd edn. Chapman \& Hall/CRC, Boca Raton, FL.

Gilks, W.R. \& Roberts, G.O. (1996) Strategies for improving MCMC. Markov chain Monte Carlo in practice (ed. by W.R. Gilks, S. Richardson and D.J. Spiegelhalter), pp. 89-114. Chapman \& Hall, New York.
Greenberg, J.D., Logsdon, M.G. \& Franklin, J.F. (2002) Introduction to geographic information systems (GIS). Learning landscape ecology: a practical guide to concepts and techniques (ed. by S.E. Gergel and M.G. Turner), pp. 17-31. Springer-Verlag, New York.

Holland, J.D., Bert, D.G. \& Fahrig, L. (2004) Determining the spatial scale of species' response to habitat. BioScience, 54, 227-233.

Hooge, P.N. \& Eichenlaub, B. (1997) Animal movement extension to ArcView version 2.0. Alaska Science Center Biological Science Office, US Geological Survey, Anchorage, AK. Available at: http://www.absc.usgs.gov/glba/gistools/ animal_mvmt.htm.

Johnson, D.H. \& Grier, J.W. (1988) Determinants of breeding distribution of ducks. Wildlife Monographs, 100, 1-37.

Kantrud, H.A. (1989) Vegetation of wetlands of the Prairie Pothole Region. Northern prairie wetlands (ed. by A. van der Walk), pp. 132-187. Iowa State University Press, Ames, IA.

Kendall, W.L., Peterjohn, B.G. \& Sauer, J.R. (1996) First-time observer effects in the North American Breeding Bird Survey. The Auk, 113, 823-829.

Krapu, G.L., Pietz, P.J., Brandt, D.A. \& Cox, R.R. (2000) Factors limiting mallard brood survival in prairie pothole landscapes. Journal of Wildlife Management, 64, 553-561.

Lawson, A.B., Browne, W.J. \& Vidal Rodeiro, C.L. (2003) Disease mapping with WinBUGS and MLwiN. John Wiley \& Sons, Chichester, UK.

Leitch, J.A. (1989) Politicoeconomic overview of prairie potholes. Northern prairie wetlands (ed. by A. van der Walk), pp. 2-14. Iowa State University Press, Ames, IA.

Lichstein, J.W., Simons, T.R. \& Franzreb, K.E. (2002) Landscape effects on breeding songbird abundance in managed forests. Ecological Applications, 12, 836-857.

Link, W.A. \& Sauer, J.R. (2002) A hierarchical analysis of population change with application to cerulean warblers. Ecology, 83, 2832-2840.

Link, W.A., Cam, E., Nichols, J.D. \& Cooch, E.G. (2002) Of $B U G S$ and birds: Markov chain Monte Carlo for hierarchical modeling in wildlife research. Journal of Wildlife Management, 66, 277-291.

Linz, G.M., Blixt, D.C., Bergman, D.L. \& Bleier, W.J. (1996) Responses of red-winged blackbirds, yellow-headed blackbirds, and marsh wrens to glyphosate-induced alterations in cattail density. Journal of Field Ornithology, 67, 167-176.

McGarigal, K., Cushman, S.A., Neel, M.C. \& Ene, E. (2002) FRAGSTATS: spatial pattern analysis program for categorical maps. Available at: http://www.umass.edu/landeco/research/ fragstats/fragstats.html (accessed 15 January 2011).

Miller, M.W. (2000) Modeling annual mallard production in the prairie-parkland region. Journal of Wildlife Management, 64, 561-575.

Mitsch, W.J. \& Gosselink, J.G. (2000) Wetlands, 3rd edn. John Wiley \& Sons, New York.

Mulhern, J.H., Nudds, T.D. \& Neal, B.R. (1985) Wetland selection by mallards and blue-winged teal. Wilson Bulletin, 97, 473-483. 
Muller, M.J. \& Storer, R.W. (1999) Pied-billed grebe (Podilymbus podiceps). The birds of North America online (ed. by A. Poole and F. Gill). Academy of Natural Sciences, Philadelphia and American Ornithologists' Union, Washington, DC. Available from: http://bna.birds.cornell.edu.bnaproxy. birds.cornell.edu/bna/species/410 (accessed 10 April 2011).

Murkin, H.R., Murkin, E.J. \& Ball, J.P. (1997) Avian habitat selection and prairie wetland dynamics: a 10-year experiment. Ecological Applications, 7, 1144-1159.

NABCI (2005) May. Bird Conservation Regions. North American Bird Conservation Initiative. Available at: http:// www.nabci-us.org/map.html (accessed 15 January 2011).

National Climatic Data Center (2002) National Climatic Data Center. Available at: http://www.ncdc.noaa.gov (daily summaries of temperature and precipitation).

Naugle, D.E., Higgins, K.F., Nusser, S.M. \& Johnson, W.C. (1999) Scale-dependent habitat use in three species of prairie wetland birds. Landscape Ecology, 14, 267-276.

Naugle, D.E., Higgins, K.F., Estey, M.E., Johnson, R.R. \& Nusser, S.M. (2000) Local and landscape-level factors influencing black tern habitat suitability. Journal of Wildlife Management, 64, 253-260.

Naugle, D.E., Johnson, R., Estey, M.E. \& Higgins, K.F. (2001) A landscape approach to conserving wetland bird habitat in the Prairie Pothole Region of eastern South Dakota. Wetlands, 21, 1-17.

Newbold, S. \& Eadie, J.M. (2004) Using species-habitat models to target conservation: a case study with breeding mallards. Ecological Applications, 14, 1384-1393.

Pribil, S. \& Picman, J. (1997) The importance of using the proper methodology and spatial scale in the study of habitat selection by birds. Canadian Journal of Zoology, 75, 1835-1844.

R Development Core Team (2007) R: a language and environment for statistical computing. $\mathrm{R}$ foundation for statistical computing, Vienna, Austria. Available at: http://www. R-project.org (accessed 25 November 2007).

Rohwer, F.C., Johnson, W.P. \& Loos, E.R. (2002) Blue-winged teal (Anas discors). The birds of North America online (ed. by A. Poole and F. Gill). Academy of Natural Sciences, Philadelphia and American Ornithologists' Union, Washington, DC. Available from: http://bna.birds.cornell.edu.bnaproxy. birds.cornell.edu/bna/species/625 (accessed 10 April 2011).

Root, T. (1988) Environmental factors associated with avian distributional boundaries. Journal of Biogeography, 15, 489505.

Saab, V. (1999) Importance of spatial scale to habitat use by breeding birds in riparian forests: a hierarchical analysis. Ecological Applications, 9, 135-141.

Sauer, J.R., Peterjohn, B.G. \& Link, W.A. (1994) Observer differences in the North American Breeding Bird Survey. The Auk, 111, 50-62.

Sauer, J.R., Fallon, J.E. \& Johnson, R. (2003) Use of North American Breeding Bird Survey data to estimate population change for bird conservation regions. Journal of Wildlife Management, 67, 372-389.
Sauer, J.R., Hines, J.E. \& Fallon, J. (2006) The North American Breeding Bird Survey, results and analysis 1966-2006. Version 6.2.2006. USGS Patuxent Wildlife Research Center, Laurel, MD.

Savard, J.-P.L., Boyd, W.S. \& Smith, G.E.J. (1994) Waterfowlwetland relationships in the aspen parkland of British Columbia: comparison of analytical methods. Hydrobiologia, 279/280, 309-325.

Spiegelhalter, D.J., Best, N.G., Carlin, B.P. \& van der Linde, A. (2002) Bayesian measures of model complexity and fit. Journal of the Royal Statistical Society, Series B, 64, 583-639. Spiegelhalter, D.J., Thomas, A. \& Best, N.G. (2003) WinBUGS Version 1.4 user manual. MRC Biostatistics Unit, Cambridge, UK. Available at: http://www.mrc-bsu.cam.ac.uk/ bugs/winbugs/manual14.pdf (accessed 1 June 2005).

Su, Z.M., Peterman, R.M. \& Haeseker, S.L. (2004) Spatial, hierarchical Bayesian models for stock-recruitment analysis of pink salmon (Oncorhynchus gorbuscha). Canadian Journal of Fisheries and Aquatic Sciences, 61, 2471-2486.

Thogmartin, W.E. (2007) Effects at the landscape scale may constrain habitat relations at finer scales. Avian Conservation and Ecology - Écologie et Conservation des Oiseaux, 2, 6. http://www.ace-eco.org/vol2/iss2/art6

Thogmartin, W.E. \& Knutson, M.G. (2007) Scaling local species-habitat relations to the larger landscape with a hierarchical spatial count model. Landscape Ecology, 22, 61-75.

Thogmartin, W.E., Sauer, J.R. \& Knutson, M.G. (2004a) A hierarchical spatial model of avian abundance with application to cerulean warblers. Ecological Applications, 14, 1766-1779.

Thogmartin, W.E., Gallant, A.L., Knutson, M.G., Fox, T.J. \& Suárez, M.J. (2004b) A cautionary tale regarding use of the National Land Cover Dataset 1992. Wildlife Society Bulletin, 32, 970-978.

Thogmartin, W.E., Knutson, M.G. \& Sauer, J.R. (2006) Predicting regional abundance of rare grassland birds with a hierarchical spatial count model. Condor, 108, 25-46.

Thogmartin, W.E., Sauer, J.R. \& Knutson, M.G. (2007) Modeling and mapping abundance of American woodcock across their breeding range in the United States. Journal of Wildlife Management, 71, 376-382.

Urban, D.L. (2005) Modeling ecological processes across scales. Ecology, 86, 1996-2006.

US Department of the Interior, Geological Survey (1992) Land use and land-cover digital data from 1:250,000 scale maps: data users guide. US Geological Survey, National Mapping Program, Reston, VA.

Venier, L.A., Pearce, J., McKee, J.E., McKenney, D.W. \& Niemi, G.J. (2004) Climate and satellite-derived land cover for predicting breeding bird distribution in the Great Lakes basin. Journal of Biogeography, 31, 315-331.

Vierling, K.T. (1999) Habitat quality, population density, and habitat-specific productivity of red-winged blackbirds (Agelaius phoeniceus) in Boulder County, Colorado. American Midland Naturalist, 142, 401-409. 
Vogelmann, J.E., Howard, S.M., Yang, L., Larson, C.R., Wylie, B.K. \& Van Driel, N. (2001) Completion of the 1990s National Land Cover Data set for the conterminous United States from Landsat Thematic Mapper data and ancillary data sources. Photogrammetric Engineering and Remote Sensing, 67, 650-652.

\section{SUPPORTING INFORMATION}

Additional Supporting Information may be found in the online version of this article:

Appendix S1 Explanatory variables and the scale at which they were evaluated from the best subset of models.

Appendix S2 Posterior distributions (natural log-transformed data) of explanatory variables in the best subset of models.

As a service to our authors and readers, this journal provides supporting information supplied by the authors. Such materials are peer-reviewed and may be re-organized for online delivery, but are not copy-edited or typeset. Technical support issues arising from supporting information (other than missing files) should be addressed to the authors.

\section{BIOSKETCH}

Greg Forcey is a practising avian ecologist for Pandion Systems, Inc., based in Gainesville, Florida. His research interests include landscape-level modelling, effects of anthropogenic structures on bird populations, and invasive species management. Supplementary research on this subject can be found at http://www.umesc.usgs.gov/terrestrial/migratory_ birds/bird_conservation_bcr11_results.html

Author contributions: G.F., W.T., G.L. and W.B conceived the ideas; G.F., W.T. and P. M. analysed the data; G.F. led the writing; and G.L. and W.B. served as graduate advisors.

Editor: Michael Patten 